\title{
Feasibility Study of Off-Grid Sustainable Energy System for Coastal Bhasan Char to Rehabilitate Rohinga Refugees
}

\author{
S.M. Zia Ul Azim, Md. Mohiuddin Uzzal, Ahmed Mortuza Saleque and Md. Abdur Rahman
}

\begin{abstract}
Government of Bangladesh (GoB) is implementing an emergency humanitarian project at coastal island Bhasan Char under Hatiya of Noakhali District, from September 2017 to temporarily rehabilitate a portion of incoming Rohinga refugees before they can repatriate to their home land, Myanmar. Under this project, GoB will carry out land development, construction of embankment as well as other infrastructures. This study is aimed at providing partial basic energy support to the government's initiative of rehabilitating 103,200 Rohinga refugees. Under the study, we check the feasibility of establishing off-grid sustainable energy system. We also perform the financial analysis of the proposed energy system by considering 20 years life-span of the project. Our study shows that annual average solar insolation in Bhasan char is $4.82 \mathrm{kWh} / \mathrm{m}^{2} /$ day and daily bright sunshine hour varies from 3 hours to 11 hours. Wind flow data of Bhasan char shows the average annual wind speed of $3.74 \mathrm{~m} / \mathrm{s}$ which is available round the clock and throughout the year. These data justify the suitability of environment friendly off-grid solar energy system as well as wind energy system for Bhasan Char. However, considering the effective generation hours, to diversify energy sources and basing on analysis result using HOMER (Hybrid Optimization of Multiple Energy Resources) software - we are proposing a hybrid energy system with $40 \%$ contribution from wind and rest $60 \%$ from solar. Our financial analysis of the project shows a total cost of 43.848 Crore (USD 0.525 Crore) over 20-year life span. Therefore, a BDT 2.192 Crore/year is quite economical and justifiable, considering the long-term impact that it might provide to displaced 103,200 refugees as well as the solution that we are providing to adverse negative socio-economic impact on Bangladesh from Rohinga issue.
\end{abstract}

Keywords: Solar Energy, Wind Energy, Sustainable Energy System, Rohinga Refugees, HOMER, Bhasan Char

\section{S.M. Zia Ul Azim}

American International University-Bangladesh

Md. Mohiuddin Uzzal

American International University-Bangladesh

Ahmed Mortuza Saleque

American International University-Bangladesh

Md. Abdur Rahman

American International University-Bangladesh

\section{Introduction}

Rohinga crisis is not new for Bangladesh. A huge influx of Rohinga refugees took place in 1991 and despite repatriation treaty between Bangladesh and Myanmar, many of them could not be sent back. They have merged with Bangladeshi population over the years. Currently, number of Rohinga refugees in Bangladesh reached to around one million. Despite of the 'Repatriation Deal' signed between Bangladesh and Myanmar, there is a high chance that thousands of them might not be sent back.

Bangladesh, itself is one of the world's most densely populated countries with a density of 1278 persons $/ \mathrm{km}^{2}$. The poverty level in Bangladesh is also very widespread and deep. As shown in Fig. 1, Bangladesh got the highest share of the Rohinga refugees that lives outside Myanmar. We can see in Fig. 2, the Rohinga refugees are making spontaneous settlements across Chittagong and that number have climbed from 99,495 to more than 547,616 outside defined camps [1]. As of mid-January 2018, there are eight new sites for Rohinga rehabilitation with occupancy of more than $2,42,000$ refugees [1].

As part of extraordinary humanitarian effort from GoB, the administration stands beside the incoming Rohinga refugees by providing them food, shelter, medical support and possibly everything. Providing daily support for one million refugees is a huge burden from socio-economic context for this small developing country Bangladesh with limited financial resources. The refugees also have destroyed a significant stretch of hilly lands and forests in Chittagong. The tourism industry in Cox's Bazar is also highly affected from this influx of refugees. There are national security concerns as well as deterioration of law and order situations from their desperate unlawful activities.

Many of the mentioned adverse negative impacts could be addressed if we can rehabilitate portion of the refugees in Bhasan Char, shown in Fig. 3, a coastal island in Noakhali district [1]. Executive Committee of the National Economic Council (ECNEC) of GoB has approved a project with estimated cost of BDT 2,312 Crore to rehabilitate 103,200 Rohinga refugees in Bhasan Char on November 2017 with a completion deadline of November 2019 [2].

In this rehabilitation project, GoB will carry out Land development, construction of embankment, building of houses, mosques, roads, water supply and sewage infrastructures, perimeter fencing, warehouses, fuel tanks, helipads, boat landing site, mobile phone towers and a radar station in Bhasan Char. Most relevantly, under the plan a power substation, solar panels and backup generators will also be installed [2]. Our objective in this research is to support GoB plan with a feasibility study on off-grid sustainable energy system for 
Bhasan Char, an island $15 \mathrm{~km}$ off Bangladesh mainland with abundant solar and wind energy resources, as shown in Fig. 4.

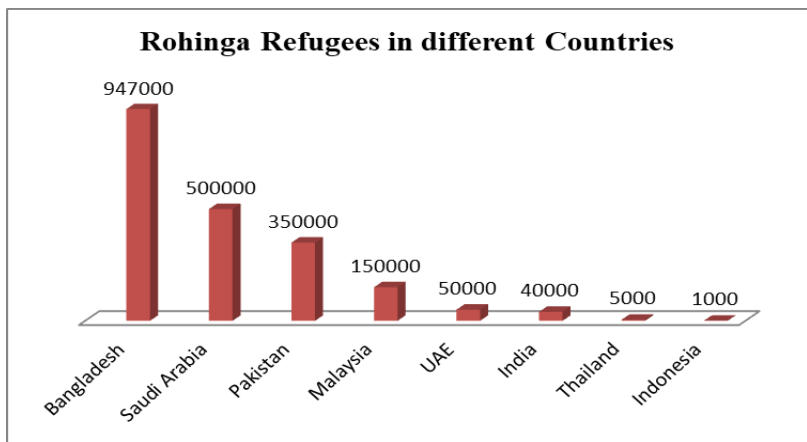

Fig. 1: Spread of Rohinga Refugees outside Myanmar [1].

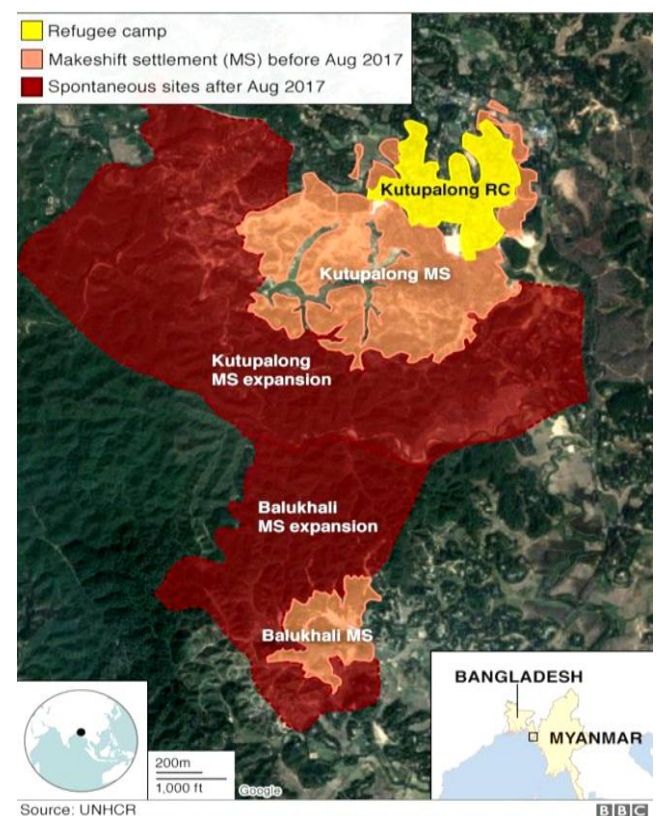

Fig. 2: Expansion of Existing Refugee Camps and Settlements [1]

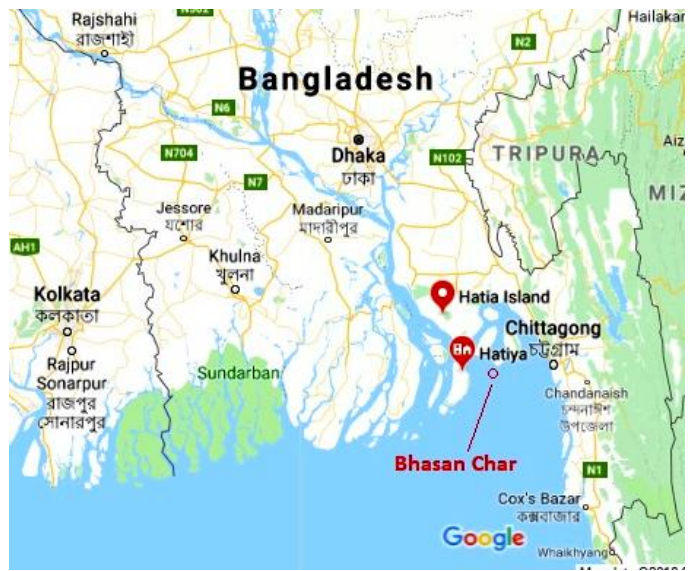

Fig.3: Location of Bhasan Char, Noakhali.

[Source: https://www.google.com/maps/hatiya/bangladesh]

This paper is organized as follows: Section II outlines our Research Methodology and Section III discusses on feasibility of Bhasan Char.
Section IV discusses on technical details of proposed system configuration. Financial analysis is done in Section V. Finally, Section VI concludes the paper with discussion of the end results.

\section{Research Methodology}

This research is carried out on the feasibility of establishing an off-grid sustainable energy system in coastal island Bhasan Char of Bangladesh. In forming the basis of the research work, the primary source was data collection from different sources and analysis using HOMER software for renewable energy based system design. Whereas, the secondary source was mainly literature review, i.e. content analysis of relevant policies, research reports, case studies, journal articles, issues from print/electronic media and internet. Our research methodology is summarized in Fig. 5.

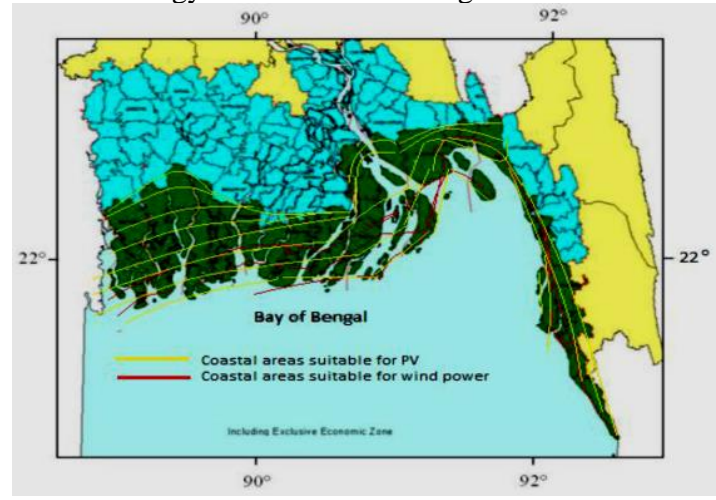

Fig.4: Coastal Areas suitable for Solar PV and Wind Power [3].

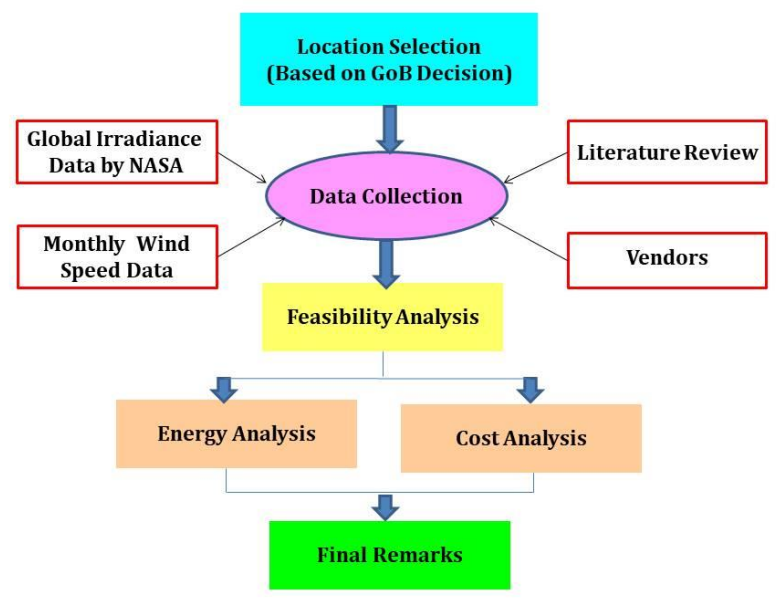

Fig.5: Research Methodology. 


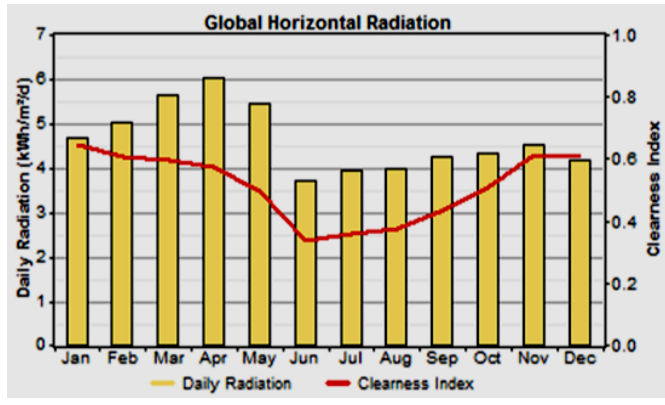

Fig.6: Monthly

Averaged

Daily

Irradiance

and

Clearness

index [4].

\section{Average Wind Speed and Solar Radiation}

\section{Average Wind Speed $(\mathrm{m} / \mathrm{s})$}

- Average Solar Radiation (kWh/m2/day)

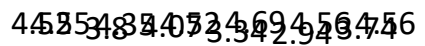

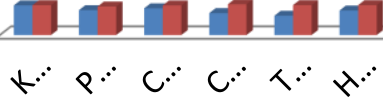

Fig.7: Average Wind Speed and Solar Irradiance at Six Coastal Stations [5] and [6].

\section{Feasibility of Bhasan Char}

harmonizing with economic optimization, improvement of power quality etc. need to be addressed holistically [7].

Sustainable social and economic development of a country largely depends upon adequate power generation capacity of a country and fuel diversification. Development of clean Renewable Energy is one of the important strategies adopted by GoB as part of Fuel Diversification Program [8]. Favorable Government policy aids Bangladesh to become the world's fastest growing country of Solar Home Systems (SHS) with a total installation of two million SHS that serves around 8.25 million people in the off-grid areas [3]. Statistics shows that Installation cost of PV or wind energy system is comparable to conventional fossil fuel electricity when we consider per unit

Table.1: Monthly Average Solar Insolation of Bhasan Char.

[Source: https://eosweb.larc.nasa.gov/sse/]

\begin{tabular}{|c|c|c|c|c|c|c|c|c|c|c|c|c|c|}
\hline \multicolumn{14}{|c|}{ Monthly Averaged Radiation Incident On An Equator-Pointed Tilted Surface (kWh/m²/day) } \\
\hline $\begin{array}{l}\text { Lat } 22.287 \\
\text { Lon } 91.343\end{array}$ & Jan & Feb & Mar & Apr & May & Jun & Jul & Aug & Sep & Oct & Nov & Dec & $\begin{array}{l}\text { Annual } \\
\text { Average }\end{array}$ \\
\hline Diffuse & 1.12 & 1.40 & 1.80 & 2.19 & 2.44 & 2.45 & 2.41 & 2.32 & 2.10 & 1.74 & 1.30 & 1.01 & 1.86 \\
\hline Direct & 6.30 & 6.13 & 5.64 & 4.83 & 3.82 & 2.44 & 2.32 & 2.67 & 2.88 & 4.20 & 5.47 & 6.47 & 4.42 \\
\hline Tilt 22 & 5.34 & 5.76 & 5.73 & 5.34 & 4.77 & 4.05 & 3.78 & 3.96 & 4.02 & 4.68 & 5.16 & 5.33 & 4.82 \\
\hline
\end{tabular}

The Power System Master Plan (PSMP) 2016 of Bangladesh, aims at formulating an extensive energy and power development plan that includes energy balance, power balance and tariff strategies up to the year 2041. Bangladesh aspires to become a high-income country by 2041, therefore various issues such as sustainable development generation cost

Attainment of United Nations Millennium Development Goals (UN MDG) and poverty alleviation of Bangladesh largely depends upon improving access to energy. The government aims to improve energy intensity, primary energy consumption/GDP, by $20 \%$ in 2030 from that of 2013 level [3]. Monthly average wind speed and solar insolation data of coastal Bangladesh is summarized in Table 1 and Table 2. The average monthly solar insolation in Bhasan Char is $4.82 \mathrm{kWh} / \mathrm{m}^{2} /$ day whereas average monthly wind speed is $3.74 \mathrm{~m} / \mathrm{s}$.

Bangladesh has considerable Renewable Energy (RE) potential with significant experience in development of renewable energy projects. The RE Development Targets of GoB is aimed at generation of additional 3,100 MW from renewable sources by 2021 and a $98 \%$ of this generation is aimed to be from solar and wind sources [9]. In the coastal areas where grid connection is not feasible or grid extension is not available, alternate electric sources like wind and solar PV can be the potential solutions. Stand-alone solar-wind-diesel hybrid energy system can be cost effective solution for the coastal regions of
Bangladesh where renewable energy is abundant [4].

Therefore, based on our holistic analysis of geographical location, government policy, available renewable energy sources, cost-benefit analysis of the hybrid energy system and long-term sustainability, Bhasan char is a very attractive and feasible solution to carry-out the 
rehabilitation project with supporting hybrid solar-wind energy system, both economically and effectively.

\section{Proposed System Configurations}

Off-Grid is a small network of electricity users with a local source of supply not depending on public utilities. Thus, for Bhasan Char offgrid energy system would be more suitable as it is remotely located in coastal Bangladesh. The long term average sunshine data indicates bright prospects for solar energy system installation which might have 4 hours to 11 hours effective generation hours [5]. Our proposed solar $\mathrm{PV}$ array has the parameters as shown in Table 3.

Table 3: Technical Parameters of PV Array [5]

\begin{tabular}{|c|c|c|}
\hline Serial & Parameter & Amount \\
\hline 1. & Output Current & DC \\
\hline 2. & Lifetime & 20 Years \\
\hline 3. & Azimuth Angle & 0 Degree \\
\hline 4. & Ground Reflection & $20 \%$ \\
\hline 5. & Slope & 22.59 Degrees South \\
\hline
\end{tabular}

Wind turbines produce electricity by using the natural power of the wind to drive a generator. The wind is a clean and sustainable fuel source, it does not create emissions and it will never run out as it is constantly replenished by energy from the sun. Most wind turbines start generating electricity at wind speeds of around 3-4 meters per second $(\mathrm{m} / \mathrm{s})$. Bhasan Char is also very suitable to have wind turbine energy generation as average monthly wind speed there is $3.74 \mathrm{~m} / \mathrm{s}$ [6]. A wind-solar hybrid power system requires relatively high capital cost for acquiring the system, but relatively low cost for Operation and Maintenance (O\&M). It can have very long service life if the system is properly maintained. It also creates employment, generates revenue, and it lowers the electricity generation cost per unit.

For this research, it is considered that each rehabilitated Rohinga family would have average 5 members and 100W Energy System would be installed for $40 \%$ of the total families rehabilitated there and taking $60 \%$ load diversification into consideration. It would thus need approximately 8000 Energy System [ $[1,03,200$ people/ 05 persons in a family) $\mathrm{x} 40 \%=8256$ Energy System]. It is also considered that power supply would be provisioned for 03 hours in the evening. Load is based on 03 LED Lights (7W each), 01 Fan (40W) and 01 TV (40W) for each family. Based on all the above considerations, requirement for a typical 100W Energy System is shown in Table 4.

Table 4: Requirement for a 100W Solar Home System.

\begin{tabular}{|c|c|c|}
\hline Serial & Requirement & Amount \\
\hline 1. & Module & 100W \\
\hline 2. & Battery Capacity & 6V-360Ah (03 Batteries) \\
\hline 3. & Controller & 30 Amp \\
\hline 4. & $\begin{array}{c}\text { Number of Load and } \\
\text { Capacity }\end{array}$ & $\begin{array}{c}\text { 03 LED Lights (3x7W), 01 Fan } \\
\text { (40W) and 01 TV (40W) }\end{array}$ \\
\hline 5. & Uses hours per day & 03 Hours \\
\hline 6 & Demanded Load & $\begin{array}{c}2400 \mathrm{kWh} / \text { day [(100W x 03 } \\
\text { hours x 8000 SHS)/1000] }\end{array}$ \\
\hline 7. & Diversity Factor & 0.6 \\
\hline
\end{tabular}

\begin{tabular}{|c|c|c|}
\hline 8. & $\begin{array}{c}\text { Total Load served } \\
(\mathrm{KWh} / \text { day })\end{array}$ & $1440 \mathrm{kWh} /$ day \\
\hline
\end{tabular}

Basing on above analysis, we may have 04 (four) different options to meet the energy requirement for Bhasan Char.

Option-1(Solar System Only): In this configuration shown in figure.8, the estimated $500 \mathrm{~kW}$ load is supported from solar system only. HOMER analysis is done with solar panels set at $22.59^{\circ}$ slope, derating factor $90 \%$ and lifetime 25 years.

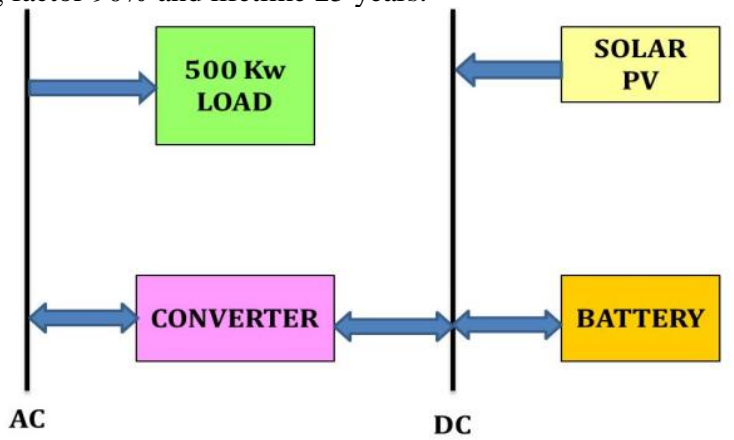

\section{Fig.8: Proposed System Configuration using Option-1(Solar System Only).}

Option-2(Wind System Only): In this configuration shown in figure. $9,500 \mathrm{~kW}$ load is supported from wind system only. HOMER analysis is done with Fuhrlander 30 Type Wind Turbine, Hub set at 25 meter height and lifetime 20 years.

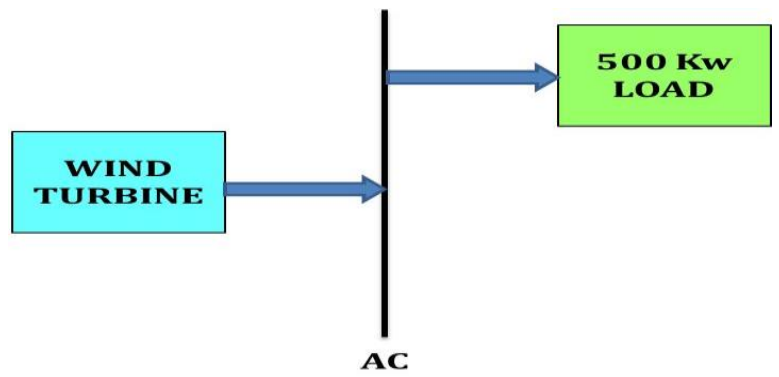

Fig.9: Proposed System Configuration using Option-2(Wind System Only).

With the mean average monthly wind speed of $3.74 \mathrm{~m} / \mathrm{s}$ the power curve comes as in Figure.10. It shows that with that average wind speed of $3.74 \mathrm{~m} / \mathrm{s}$, the output power is about $4 \mathrm{~kW}$ per wind turbine.

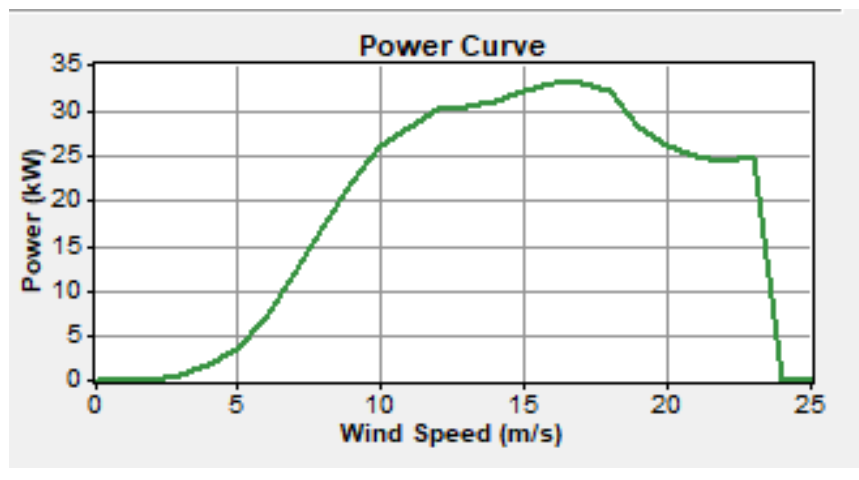

Fig.10: Power Curve output from HOMER for Wind System Only. 
Option-3(Solar-Wind Hybrid System): In this configuration shown in figure. $11,500 \mathrm{~kW}$ load is supported from Solar-Wind Hybrid Energy System. HOMER analysis is done considering 60\% (300 kW) contribution from Solar and 40\% (200 kW) contribution from Wind resources.

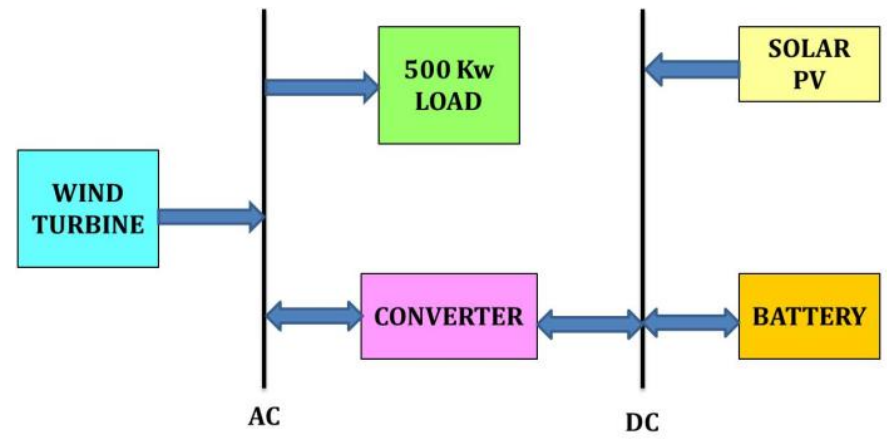

Fig.11: Proposed System Configuration using Option-3(Solar Wind Hybrid Energy System).

Option-4(Solar-Wind Standalone System): In this configuration shown in figure.12, 500kW load is supported from Solar-Wind Standalone System. HOMER analysis here is also done considering $60 \%(300 \mathrm{~kW})$ contribution from Solar and 40\% (200 kW) contribution from Wind resources.

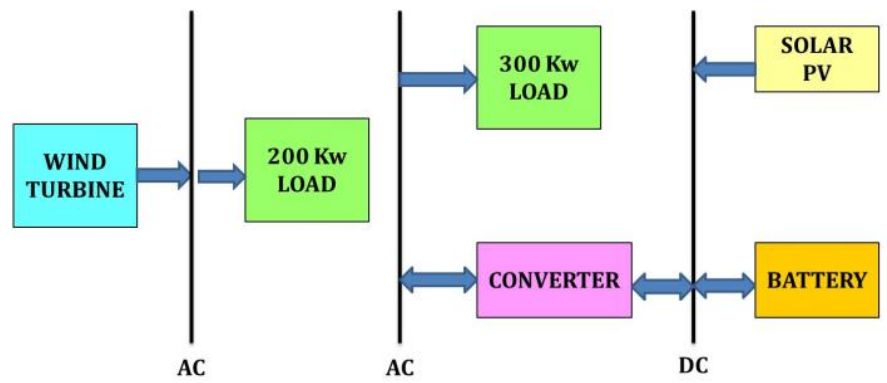

Fig.12: Proposed System Configuration using Option-4(Solar Wind Standalone System).

\section{Financial Analysis}

Proposed energy systems consist of components such as Photovoltaic (PV) Array, wind turbines, battery, converter etc. at different combinations. Technical parameters and cost assumptions for each are given below which are considered as inputs for analyzing through HOMER. Finally, the Financial Analysis for the whole system is done.

Table 5: Cost Analysis for Solar PV Array.

\begin{tabular}{|l|l|l|}
\hline \multicolumn{1}{|c|}{ Parameter } & \multicolumn{1}{c|}{ Unit } & \multicolumn{1}{c|}{$\begin{array}{c}\text { Value } \\
\text { (BDT) }\end{array}$} \\
\hline Capital Cost & BDT/W & 100 \\
\hline Replacement Cost & BDT/W & 50 \\
\hline Operation and Maintenance Cost & BDT/W/Yr & 50 \\
\hline Lifetime & Years & 25 \\
\hline Derating Factor & Percent & 90 \\
\hline
\end{tabular}

A generic $3 \mathrm{~kW}$ wind turbine is considered for the concerned proposed systems. Technical parameters and cost assumptions $(1 \mathrm{USD}=83.50$ BDT) are stated below:

Table 6: Cost Analysis for Wind Turbine

\begin{tabular}{|l|l|l|}
\hline \multicolumn{1}{|c|}{ Parameter } & Unit & \multicolumn{1}{c|}{ Value (BDT) } \\
\hline Capital Cost & BDT/kW & $2,50,000$ \\
\hline Replacement Cost & BDT/kW & $1,50,000$ \\
\hline $\begin{array}{l}\text { Operation and } \\
\text { Maintenance Cost }\end{array}$ & $\begin{array}{l}\text { BDT/Yr/ } \\
\text { Turbine }\end{array}$ & 5000 \\
\hline Lifetime & Years & 20 \\
\hline
\end{tabular}

Lead Acid (Trojan L16P 6V Long-Life Deep Cycle) batteries would be utilized for storage. The technical and economic parameters (1 $\mathrm{USD}=83.50 \mathrm{BDT}$ ) are stated below:

Table 7: Cost Analysis for Battery

\begin{tabular}{|l|l|l|}
\hline \multicolumn{1}{|c|}{ Parameter } & Unit & Value (BDT) \\
\hline Capital Cost & $\mathrm{BDT} / \mathrm{kWh}$ & 7,000 \\
\hline Replacement Cost & $\mathrm{BDT} / \mathrm{kWh}$ & 6,000 \\
\hline $\begin{array}{l}\text { Operation and } \\
\text { Maintenance Cost }\end{array}$ & $\mathrm{BDT} / \mathrm{kWh} /$ Year & 500 \\
\hline Lifetime & Years & 3 \\
\hline
\end{tabular}

Most of the house appliances are compatible for AC current nowadays. As the electricity generated from the PV or wind turbine is DC, converter is needed to change it into AC.

Table 8: Cost Analysis for Converter

\begin{tabular}{|l|l|l|}
\hline \multicolumn{1}{|c|}{ Parameter } & \multicolumn{1}{c|}{ Unit } & \multicolumn{1}{c|}{ Value (BDT) } \\
\hline Capital Cost & $\mathrm{BDT} / \mathrm{kW}_{\text {rated }}$ & 10,000 \\
\hline Replacement Cost & $\mathrm{BDT} / \mathrm{kW}_{\text {rated }}$ & 10,000 \\
\hline Lifetime & Years & 20 \\
\hline
\end{tabular}

The monthly average electric production for solar-wind hybrid energy system is shown in figure 13. From the monthly average power generation curve it can be seen that for January month the average electricity generation is $118 \mathrm{~kW}$. Typical day length at Bhasan Char for the month of January is approximately 10 hours. Hence the total electricity production in January will be $(118$ X 10) kW i.e. $1180 \mathrm{~kW}$ which is only $18 \%$ lesser than the targeted $1500 \mathrm{~kW}$ generation. However this size of installation is economically justified as simulated in HOMER software and presented in table 9. 


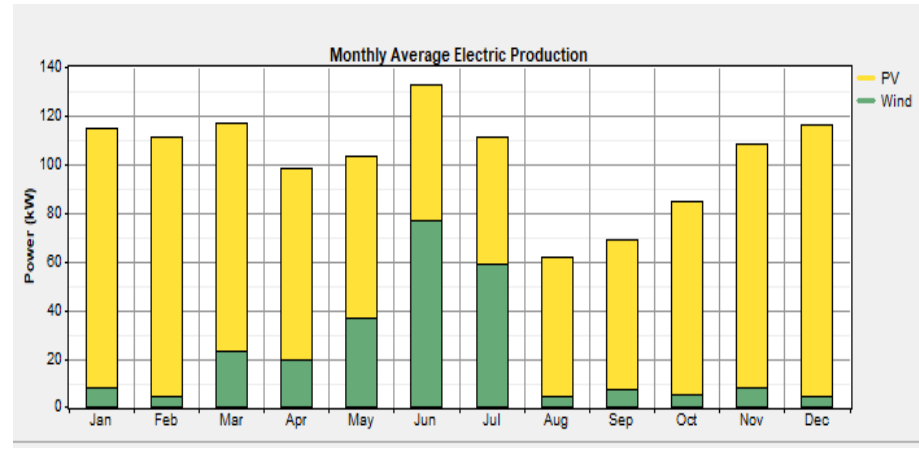

Fig.13: Monthly Average Electric Production for Proposed SolarWind Hybrid Energy System (Option-3) Configuration.

The associated cost of each component is given in Table 5 to Table 8 . We gave theses costs as input to HOMER and generated the energy costs associated with the proposed 4 configurations, as summarized in table 9 .

Table 9: Category wise Optimization Results

\begin{tabular}{|c|c|c|c|c|c|c|c|c|}
\hline Type & $\mathbf{P V}(\mathbf{k W})$ & $\begin{array}{c}\text { Wind } \\
\text { Turbines } \\
(\mathbf{k W})\end{array}$ & $\begin{array}{c}\text { Battery } \\
\text { (Nos.) }\end{array}$ & Conv $(\mathbf{K W})$ & $\begin{array}{c}\text { Initial Capital } \\
(\mathbf{B D T})\end{array}$ & $\begin{array}{c}\text { Operating } \\
\mathbf{C o s t} \\
(\mathbf{B D T} / \mathbf{Y r})\end{array}$ & Total NPC & $\begin{array}{c}\text { COE } \\
(\mathbf{B D T} / \mathbf{k W h})\end{array}$ \\
\hline Solar & 500 & - & 17100 & 1000 & $22,38,47,969$ & $2,57,04,557$ & $44,26,85,187$ & 96.03 \\
\hline Wind & - & 3000 & 11400 & 1000 & $88,57,39,276$ & $53,13,606$ & $93,09,76,904$ & 201.99 \\
\hline $\begin{array}{c}\text { Solar-Wind } \\
\text { Hybrid }\end{array}$ & $\mathbf{4 0 0}$ & $\mathbf{2 1 0}$ & $\mathbf{1 1 4 0 0}$ & $\mathbf{1 0 0 0}$ & $\mathbf{2 6 , 1 4 , 5 3 , 9 4 8}$ & $\mathbf{2 , 0 7 , 9 3 , 0 8 7}$ & $\mathbf{4 3 , 8 4 , 7 6 , 9 5 4}$ & $\mathbf{9 5 . 1 9}$ \\
\hline $\begin{array}{c}\text { Stand Alone } \\
\text { Solar }\end{array}$ & 500 & - & 3800 & 600 & $6,15,95,946$ & $2,52,75,116$ & $29,10,18,876$ & 98.69 \\
\hline $\begin{array}{c}\text { Stand Alone } \\
\text { Wind }\end{array}$ & - & 900 & 15200 & 400 & $22,73,36,265$ & $33,69,225$ & $25,79,18,975$ & 131.35 \\
\hline
\end{tabular}

From the optimization results, it is found that Solar-Wind Hybrid Energy System would cost lowest and thus would be the most feasible option.

Table 10: Electrical Production for Proposed Solar-Wind Hybrid Energy System

\begin{tabular}{|c|c|c|}
\hline Production & $\mathbf{k W h} / \mathbf{Y r}$ & \% \\
\hline PV Array & $7,09,589$ & 79 \\
\hline Wind Turbines & $1,86,661$ & 21 \\
\hline Total & $8,96,250$ & 100 \\
\hline
\end{tabular}

Table 11: Electrical Consumption for Proposed Solar-Wind Hybrid Energy System

\begin{tabular}{|l|l|c|}
\hline \multicolumn{1}{|c|}{ Consumption } & $\mathbf{k W h} / \mathbf{Y r}$ & $\mathbf{\%}$ \\
\hline AC Primary Load & $5,41,252$ & 100 \\
\hline Total & $5,41,252$ & 100 \\
\hline
\end{tabular}

Table 12: Electrical Quantity for Proposed Solar-Wind Hybrid Energy System

\begin{tabular}{|c|c|c|}
\hline Quantity & $\mathbf{k W h} / \mathbf{Y r}$ & $\%$ \\
\hline Excess Electricity & $2,31,477$ & 25.8 \\
\hline $\begin{array}{ll}\text { Unmet } & \text { Electric } \\
\text { Load } & \end{array}$ & 42.7 & 0.0 \\
\hline
\end{tabular}

\begin{tabular}{|l|l|l|}
\hline Capacity Shortage & 95.1 & 0.0 \\
\hline
\end{tabular}

The Government energy facilities planned for Bhasan Char are a power sub-station, solar panels and backup generators. It is assumed that government facilities will support the public utilities. Solar-Wind Hybrid Energy System proposed in this research will be used for residential use only. It will store energy in the batteries and this energy will be used for 03 hours from the evening to extend their effective work hours and to develop skills and educational background for upcoming future.

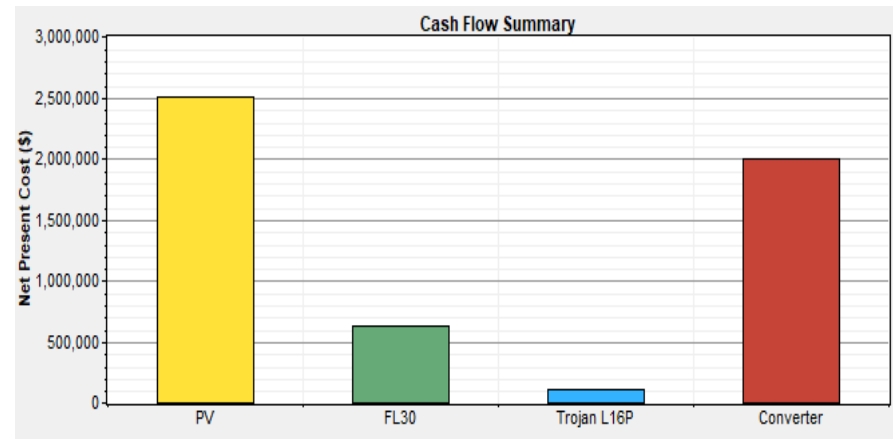

Fig.14: Cost Summary for Proposed Solar-Wind Hybrid Energy System (Option-3) Configuration.

The cash flow summary for solar-wind hybrid energy system is shown in figure.14. It shows that PV cells and Converters are major cost 
components. Considering the life time of the project as 20 years, the total Cost for the Solar Wind Hybrid Energy System is shown Table 13 .

Table 13: Cost Summary for Proposed Solar-Wind Hybrid Energy System (Option-3) Configuration.

\begin{tabular}{|l|c|c|c|c|c|}
\hline \multicolumn{1}{|c|}{ Component } & $\begin{array}{c}\text { Capital Cost } \\
(\text { BDT) }\end{array}$ & $\begin{array}{c}\text { Replacement } \\
\text { Cost (BDT) }\end{array}$ & $\begin{array}{c}\text { O\&M Cost } \\
\text { (BDT) }\end{array}$ & $\begin{array}{c}\text { Salvage } \\
\text { (BDT) }\end{array}$ & $\begin{array}{c}\text { Total Cost } \\
\text { (BDT) }\end{array}$ \\
\hline PV & $3,99,99,924$ & 0 & $17,02,71,530$ & $-5,94,604$ & $20,96,76,934$ \\
\hline Wind Turbine & $4,99,99,967$ & 0 & $28,52,026$ & 0 & $5,28,51,993$ \\
\hline Battery Pack & $47,88,057$ & $15,82,242$ & $29,11,729$ & 0 & $92,82,027$ \\
\hline Converter & $16,66,66,000$ & 0 & 0 & 0 & $16,66,66,000$ \\
\hline System & $\mathbf{2 6 , 1 4 , 5 3 , 9 4 8}$ & $15,82,242$ & $17,60,35,285$ & $-5,94,604$ & $\mathbf{4 3 , 8 4 , 7 6 , 9 5 4}$ \\
\hline
\end{tabular}

Finally, we carried out a cash-flow analysis of this Solar-Wind Hybrid Energy System with a yearly discounted rate of $10 \%$. We consider all the yearly associated cost and discounted it at $10 \%$ rate to calculate overall present value of the 20 year long project life span.

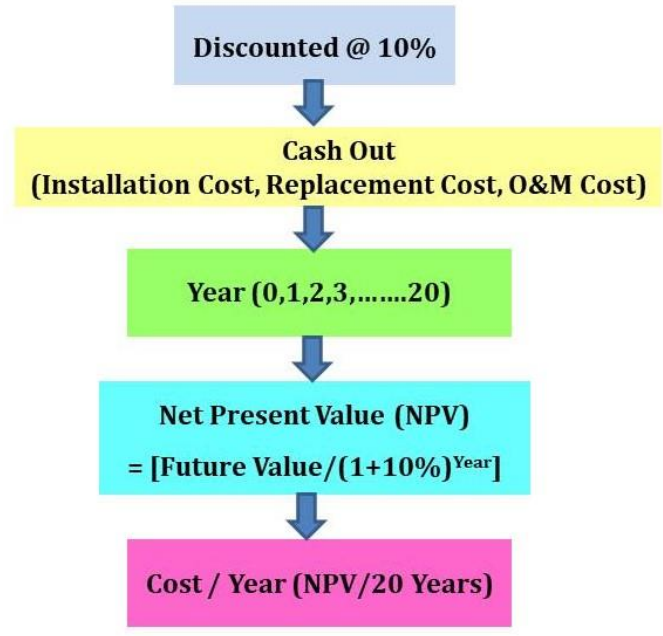

Fig.15: Cash Flow Analysis Process.

From our cash flow analysis, we had found that NPV of this hybrid energy to be BDT 43.848 crore over 20 year life span. Therefore, a BDT 2.192 Crore/year is quite economical and justifiable, considering the long-term impact that it might provide to displaced 103,200 refugees as well as the solution that we are providing to adverse negative socio-economic impact on Bangladesh from Rohinga issues

\section{Conclusion}

Bangladesh Government has planned to rehabilitate a total of 1,03,200 Rohinga Refugees in Bhasan Char. And this Solar-Wind Hybrid Energy System Project has been proposed to support $40 \%$ of them by establishing 8000 energy system on charity basis beside energy facilities established by the Government. Initially funding may not be a problem from Donor Agency (ies) if this feasibility study can be justified. This facility may be further extended with allocation of additional budget from GoB or Donors. The Net Present Value (NPV) of the Solar Wind Hybrid Energy System would be BDT 43.848 Crore (USD 0.525 Crore). And the cost per year would be BDT 2.192 Crore.
This is surely going to be a very noble humanitarian effort resulting in skill development of distressed Rohingas. This would support children education in the evening, strengthen existing security measures adopted by the local administration and ensure better survival of the Rohinga refugees where number of beneficiaries is also quite high. Moreover, since the expenditure is not much, funding for this project is also not supposed to be a problem.

This Project has been proposed for 20 years support. But Government has plan for temporary rehabilitation of the distressed Rohingas. A lot of development is expected there over the 20 year life span. Rohinga refugees would be rehabilitated in Bhasan Char for the time being after it is made habitable. After the Rohingas return to their home land, small number of Bangladeshi population may be settled there easing the population problem even by a bit. Provision of Solar-Wind Hybrid energy system in Bhasan Char would promote 'Green Energy' by avoiding the environmental hazards due to use of fossil fuel or coal for electricity generation. Moreover, with the implementation of ongoing development project works, Bhasan Char is expected to have bright prospects of tourism in the near future. Requirement of energy in Bhasan Char, its geographical location, availability of solar and wind resources in the island, effort of provisioning 'Green Energy' and above all economic suitability justifies the feasibility of establishing Off Grid Solar Wind Hybrid Energy System for coastal island Bhasan Char to strengthen Rohinga Rehabilitation plan.

\section{References}

[1] 'Myanmar Rohinga: What you need to know about the Crisis', 16 January 2018, [http://www.bbc.com/news/world-asia-41566561].

[2] Islam, Md Shafiqul, 'Rohinga Rehabilitation Plan in Bhasan Char at a Glance', published in Bangla Tribune, at 11:38 AM 03 December 2017.

[3] Alam, M. and Bhattacharyya, S., 'Decentralized Renewable Hybrid MiniGrids for Sustainable Electrification of the Off-Grid Coastal Areas of Bangladesh', in Energies Journal, April 2016.

[4] Zubair, A., Tanvir, A.A. and Hasan, Md Mehedi, 'Optimal Planning of Standalone Solar-Wind-Diesel Hybrid Energy System for a Coastal Area of Bangladesh', in International Journal of Electrical and Computer Engineering (IJECE), Vol.2, No.6, December 2012.

[5] Podder, S., Khan, R.S. and Mohon, S.M. Ashraful Alam, 'The Technical and Economic Study of Solar-Wind Hybrid Energy System in Coastal Area of Chittagong, Bangladesh', in Hindawi Publishing Corporation Journal of Renewable Energy, Vol 2015, Article ID 482543.

[6] Islam, Md. Robiul, Rahman, Md. Nazibur and Mannan, Md. Abdul, 'Study Of Wind Power In Different Parts Of Bangladesh', in International 
Research Journal of Engineering and Technology (IRJET),Vol.3 Issue.9, Sep-2016.

[7] Power Division, Ministry of Power, Energy and Mineral Resources, Government of the People's Republic of Bangladesh supported by Japan International Cooperation Agency (JICA), Tokyo Electric Power Services Co. Ltd. Tokyo Electric Power Company Holdings Inc, 'Power System Master Plan 2016 Summary', September 2016.

[8] Amin, Md. Ruhul, 'Cost Effective Solar Wind Hybrid Power System for Coastal Area', M.Sc Engineering Research Report, BUET, May 2015.

[9] Government of the People's Republic of Bangladesh Sustainable and Renewable Development Authority (SREDA) Power Division Ministry of Power, Energy \& Mineral Resources www.sreda.gov, 'Scaling Up Renewable Energy in Low Income Countries (SREP)-Investment Plan for Bangladesh' October 2015.

[10] Miah, M.A.R., Rahman, M.M. and Kabir, Runa, 'Selection of the Most Appropriate Off-Grid Hybrid System for Rural and Coastal Areas in Bangladesh Using Analytical Hierarchy Process (AHP)', in International Journal of Sustainable and Green Energy, Vol. 5, No. 5, 2016.

[11] Muhtadi, Abir, 'Modeling and Simulation of a Microgrid consisting Solar PV \& DFIG based Wind Energy Conversion System for St. Martin's Island', in M.Sc in Electrical and Electronic Engineering Research Report, AIUB, October 2017.

[12] Sustainable and Renewable Energy Development Authority (SREDA) and Power Division, Ministry of Power, Energy and Mineral Resources, Government of the People's Republic of Bangladesh, 'Energy Efficiency and Conservation Master Plan up to 2030',March 2015

[13] Hasan, M. and Momin, Oishe Binty, 'Performance Analysis and Feasibility Study of Solar-Wind-Diesel Hybrid Power System in Rura Areas of Bangladesh', in International Journal of Engineering Research and General Science, Vol 3, Issue 5, September-October, 2015.

[14] Khadem, S.K., 'Feasibility study of Wind Home System in Coastal Region of Bangladesh', Renewable Energy Research Centre, University of Dhaka.

[15] Asian Development Bank Report, 'Improving Lives of Rural Communities Through Developing Small Hybrid Renewable Energy Systems', Published in 2017.

[16] Alam, Majbaul and Bhattacharyya, Subhes, 'Decentralized Renewable Hybrid Mini-Grids for Sustainable Electrification of the Off-Grid Coastal Areas of Bangladesh',in MDPI Energies Journal, Basel, Switzerland, 6 April 2016.

[17] Kabir, Ehsanul, Kim, Ki-Hyun and Szulejko, Jan E., 'Social Impacts of Solar Home Systems in Rural Areas: A Case Study in Bangladesh', in MDPI Energies Journal, Basel, Switzerland, 16 October 2017.

[18] Lipu, Molla Shahadat Hossain, Uddin, Md. Shazib and Miah, Muhammad Ahad Rahman, 'A Feasibility Study of Solar-Wind-Diesel Hybrid System in Rural and Remote Areas of Bangladesh', in International Journal of Renewable Energy Research, Vol.3, No.4, 2013.

[19] Saifullah, A.Z.A, Karim, Md. Abdul and Karim, Md. Raisul, 'Wind Energy Potential in Bangladesh', in American Journal of Engineering Research (AJER), Volume-5, Issue-7, pp-85-94, 2016.

[20] Aziz, Muhammad Shahazad, Ahmed, Sohaib, Saleem, Umair and Mufti, Gussan Maaz, 'Wind-hybrid Power Generation Systems Using Renewable Energy Sources-A Review', in International Journal of Renewable Energy Research, Vol.7, No.1, 2017.

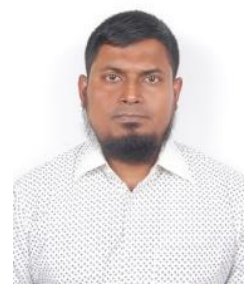

S.M. Zia-Ul-Azim earned Bachelor of Science in Electrical and Electronic Engineering from Bangladesh University of Engineering \& Technology (BUET) in 1997. He completed Masters of Defence Studies from National University Bangladesh in 2002 and Masters of Philosophy (Part-1) from Bangladesh University of Professionals (BUP) in 2011. Currently he is pursuing Masters of Science in Electrical and Electronic Engineering at American International University Bangladesh (AIUB). $\mathrm{He}$ is presently serving Military Institute of Science and Technology (MIST), Mirpur Cantonment.

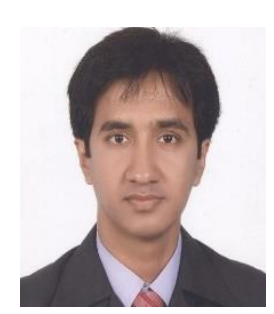

Mohammad M Uzzal received B.Sc. degree in Electrical and Electronic Engineering from BUET, Dhaka, Bangladesh in 2002 and M.S.E. degree in Electrical Engineering from Arizona State University (ASU), AZ, USA in 2006. He earned a Ph.D. degree in micro-electronics with a research focus in mixed signal CMOS circuits for Bio-sensing application from University of New Mexico, NM, USA. From 2004 to 2012, he was with American International University - Bangladesh as a Fulltime Faculty in Electrical and Electronic Engineering Department. From May to Dec. 2014, he was with Intel Corporation, Santa Clara, $\mathrm{CA}$ and worked on next generation high speed (10-16Gbps) I/O design and simulation. His research interest includes analog/RF and mixed signal circuit design, low cost bio-sensors and nano-electronics.

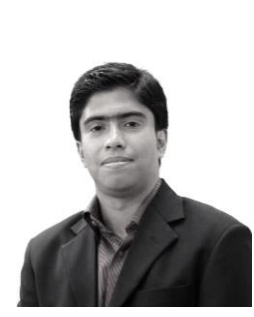

Ahmed Mortuza Saleque received Bachelor Degree in Electrical and Electronic Engineering from American International University, Bangladesh in 2010. In the same year he joined the Department of Electrical and Electronic Engineering, American International UniversityBangladesh (AIUB) as Lecturer. He received Master of Engineering in Telecommunications from American International UniversityBangladesh in 2012. Both in his Bachelor and Master's, he received the prestigious Summa Cum Laude distinction.

From 2013 to 2015, he was awarded Erasmus Mundus scholarship for Master's program. He received joint Master degree in Sustainable Transportation and Electrical Power Systems (EMMC-STEPS) from University of Wisconsin Madison, USA, University of Nottingham, UK, University of Oviedo, Spain and University of Rome, Italy.

He was Visiting Scholar at the Wisconsin Electric Machines and Power Electronics Consortium (WEMPEC), University of WisconsinMadison, USA, in 2015. He is currently working as an Assistant Professor, Department of EEE, American International UniversityBangladesh (AIUB). His research interests include Electric Drives, Deadbeat Direct Torque and Field Oriented Control (DB-DTFC), Power Electronics, Electric and Hybrid Vehicle Technology, Digital Control and Signal Processing.

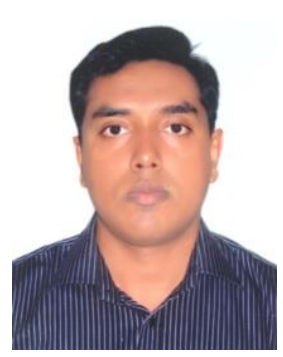

Md. Abdur Rahman received his $\mathrm{PhD}$ in wireless communications from Tokyo Institute of Technology, Japan in 2013. He received BSc Engg. and M.E. degrees from American International University Bangladesh (AIUB) and Asian Institute of Technology (AIT), Thailand, respectively. He joined AIUB as a lecturer in 2002, and currently employed as Professor and Associate Dean of the Faculty of Engineering in the same university. His recent research interests include cognitive radio, bioinformatics, wireless systems, ICT etc. At present, he is conducting postdoctoral research in the School of Engg. and IT at Federation University Australia. He is a Life member of IEB and senior member of IEEE. During his doctoral studies he lead a team of students formed by both undergraduate and postgraduate students for designing an emergency wireless network. The team took part in four international research competitions and won four prizes. 